\title{
OPTIMASI PROSES PEMBUATAN TEPUNG LABU KUNING MENGGUNAKAN RESPONSE SURFACE METHODOLOGY UNTUK MENINGKATKAN AKTIVITAS ANTIOKSIDANNYA
}

\author{
[Optimization of Pumpkin Flour Manufacturing Using \\ Response Surface Methodology to Enhance its Antioxidant Activities] \\ Agung Wahyono ${ }^{1)}$, Elly Kurniawati ${ }^{1)}$, Kasutjianingati ${ }^{2)}$, Kang-Hyun Park ${ }^{3)}$, \\ dan Woo-Won Kang ${ }^{3) *}$ \\ 1) Program Studi Teknologi Industri Pangan, Politeknik Negeri Jember, Jember, Indonesia \\ 2) Program Studi Produksi Tanaman Hortikultura, Politeknik Negeri Jember, Jember, Indonesia \\ 3) Departement of Food and Food Service Industry, Kyungpook National University, Korea
}

Diterima 24 Januari 2018 / Disetujui 26 Maret 2018

\begin{abstract}
Yellow pumpkin (Cucurbita moscata) is a popular plant in Indonesia, but its utilization is limited. It has been reported that the antioxidant activity of the yellow pumpkin increased by increasing the drying temperature and immersing the pumpkin in bisulfite solution during processing. The aim of this study was to optimize the processing conditions for the manufacturing of pumpkin flour using Response Surface Methodology (RSM) to enhance its antioxidant activities. The optimization process was done using a Box-Behnken construction. The factorial treatments consisted of immersion in metabisulfite solution, drying temperature, and drying time. The results showed that the scavenging activity as measured by DPPH and ABTS corresponded well to the independent variables based on the multiple regression analysis particularly the multivariate quadratic regression (MQR). Based on the MQR, the determination coefficients (R2) of DPPH and ABTS were 0.97 and 0.96 , respectively. Based on that model, the optimum conditions of pumpkin flour manufacturing were immersion in metabisulfite solution for $23.05 \mathrm{~min}$, drying temperature of $85^{\circ} \mathrm{C}$, and drying time of $11.40 \mathrm{~h}$. This optimum condition was predicted to yield pumpkin flour having DPPH and ABTS scavenging activities of $90.12 \%$ and $94.38 \%$, respectively. Based on the validation data, the optimum condition resulted in flour with antioxidant activities of 80.23 (DPPH) and $86.67 \%$ (ABTS). The quadratic models developed were powerful in predicting the actual values of the antioxidant activity by $D P P H$ and ABTS. The accuracy of the models in predicting the antioxidant activity by DPPH and ABTS were 89.02 and $91.83 \%$, respectively.
\end{abstract}

Keywords: antioxidant, flour, pumpkin, RSM

\begin{abstract}
ABSTRAK
Labu kuning (Cucurbita moscata) merupakan tanaman yang populer di Indonesia, tetapi pemanfaatannya masih sangat terbatas. Telah dilaporkan bahwa aktivitas antioksidan labu kuning meningkat dengan peningkatan suhu pengeringan dan perendaman awal menggunakan metabisulfit. Tujuan dari penelitian ini adalah melakukan optimasi kondisi produksi tepung labu kuning dengan menggunakan Response Surface Methodology (RSM) untuk meningkatkan aktivitas antioksidan. Proses optimasi dilakukan dengan menggunakan konstruksi Box-Behnken. Perlakuan faktorial menggunakan 3 variabel independen yang meliputi lama perendaman bisulfit, suhu pengeringan, dan lama pengeringan. Hasil penelitian, menunjukkan bahwa aktivitas antioksidan (DPPH dan ABTS) berkorelasi baik dengan variable independen (lama perendaman, suhu pengeringan dan waktu pengeringan) menurut analisis regresi berganda khususnya model regresi kuadrat multivariate (multivariate quadratic regression). Nilai koefisien determinasi $\left(R^{2}\right)$ untuk DPPH dan ABTS masing-masing adalah 0,97 dan 0,96. Berdasarkan model tersebut, diperoleh kondisi optimum untuk memproduksi tepung labu kuning yaitu perendaman natrium metabisulfit selama 23,05 menit, suhu pengeringan $85^{\circ} \mathrm{C}$, dan waktu pengeringan 11,40 jam. Kondisi optimum tersebut diprediksi akan dapat menghasilkan tepung labu kuning dengan aktivitas DPPH 90,12\% dan ABTS 94,38\%. Berdasarkan hasil validasi, kondisi prosesing optimum tersebut menghasilkan aktivitas antioksidan DPPH dan ABTS masing-masing sebesar 80,23 dan 86,67\%. Model kuadratik mampu menduga nilai aktual aktivitas antioksidan DPPH dan ABTS dengan akurasi masing-masing sebesar 89,02 dan 91,83\%.
\end{abstract}

Kata kunci: antioksidan, labu, RSM, tepung

\footnotetext{
*Penulis Korespondensi:
}

Email: wwkang@knu.ac.kr 


\section{PENDAHULUAN}

Labu kuning (Cucurbica moschata) adalah tanaman lokal yang ketersediaannya cukup melimpah. Pada tahun 2014, dilaporkan bahwa produksi Labu kuning secara nasional adalah sebesar 523.063 ton. Saat ini, pemanfaatan labu kuning sebagai bahan pangan masih terbatas pada pengolahan sederhana. Beberapa produk olahan telah dikembangkan seperti biskuit, roti, kerupuk, keripik dan beberapa jenis kue basah. Akan tetapi ketersediaan produk olahan tersebut di masyarakat masih sedikit. Hal ini disebabkan oleh keterbatasan teknologi pengolahan labu kuning yang dimiliki oleh masyarakat. Selain itu, kesadaran masyarakat untuk mengonsumsi bahan pangan kaya nutrisi masih rendah. Untuk itu, edukasi, sosialisasi, dan transfer teknologi diperlukan untuk mendukung peningkatan pemanfaatan labu kuning.

Labu kuning merupakan bahan pangan yang kaya serat pangan terutama pektin, senyawa bioaktif, beta karoten, vitamin $A$, tocopherol, vitamin lain termasuk B6, K, C, thiamine, dan riboflavin, serta beberapa jenis mineral ( $\mathrm{K}, \mathrm{P}, \mathrm{Mg}, \mathrm{Fe}$ dan $\mathrm{Se})$. Kandungan serat pangan yang tinggi dalam bentuk pektin dapat mengontrol level serum insulin, menurunkan tingkat gula darah, meningkatkan toleransi glukosa dan memberikan proteksi terhadap berbagai penyakit seperti diabetes, penyakit kardiovaskular, konstipasi serta kanker usus besar (Rakcejeva et al., 2011; Adams et al., 2011). Aydin dan Gocmen (2015) melaporkan bahwa aktivitas antioksidan tepung labu kuning meningkat secara signifikan dengan perlakuan pengeringan oven dan perlakuan awal perendaman menggunakan metabisulfit.

Salah satu alternatif pengolahan labu kuning yang saat ini menjadi pilihan adalah dibuat menjadi tepung. Tepung labu kuning menjadi pilihan karena produk dapat disimpan untuk jangka waktu yang lama dan dengan mudah diolah menjadi bahan pangan formulasi (Que et al., 2008), terutama produk bakery, sup, mie instan, pasta dan tepung composit sebagai pengayaan bahan fungsional dan bahan pewarna alami (Dhiman et al., 2009).

Response Surface Methodology (RSM) merupakan metode statistik untuk menentukan korelasi antara variabel respon dan sekelompok variabel input (Khuri dan Mukhopadhyay, 2010). RSM merupakan metode statistik dan matematik yang berguna untuk membangun, mengembangkan dan mengoptimasi proses baik untuk formulasi produk baru maupun produk yang sudah lama diproduksi (Myers et al., 2016). Saat ini RSM telah menjadi salah satu metode optimasi yang paling populer dalam bidang teknologi dan rekayasa pangan. Ratusan publikasi dalam jurnal bereputasi dan berimpak faktor yang menggunakan RSM untuk optimasi proses dapat dengan mudah diperoleh. Beberapa paper yang meng- gunakan RSM untuk optimasi proses diantaranya adalah 1. Optimasi formulasi kandungan nutrisi roti berbasis kalsium karbonat dan inulin (Salinas dan Puppo, 2015); 2. Overproduksi inulinase dan optimasi hidrolisis inulin menggunakan yeast Pichia guilliermondii (Guo et al., 2009); 3. Optimasi ekstraksi phycocyanin dari microalga Spirulina platensis menggunakan Ultra-sound Assisted Extraction (UEA) (Hadiyanto dan Suttrisnorhadi, 2016); 4. Hidrolisis enzimatik protein isolat dari minyak labu kuning yang dibuat dari biji labu kuning tanpa kulit (Peričin et al., 2009); dan 5. Optimasi produksi inulinase pada medium padat menggunakan Aspergillus ficuum JNSP5-06 (Chen et al., 2011).

Sampai saat ini, masih belum ditemukan publickasi hasil penelitian mengenai proses pembuatan tepung labu kuning dengan optimasi aktivitas antioksidan menggunakan RSM. Oleh karena itu dalam penelitian ini dilakukan optimasi proses pembuatan tepung labu kuning dengan menggunakan RSM terhadap kondisi proses yang terdiri dari lama perendaman natrium metabisulfit, suhu pengeringan dan lama pengeringan untuk mengoptimalkan aktivitas antioksidan.

\section{BAHAN DAN METODE}

\section{Bahan}

Bahan utama pembuatan tepung yang digunakan dalam penelitian ini adalah labu kuning (Cucurbica moschata) yang bebas dari kerusakan fisik, mempunyai warna kulit yang relatif seragam yang diperoleh dari supermarket lokal di Sangju, Korea. Labu kuning yang digunakan merupakan labu yang sudah mengalami penyimpanan lebih kurang 4 bulan (dipanen pada akhir musim gugur).

\section{Pembuatan tepung labu kuning}

Labu kuning dicuci dengan menggunakan air bersih yang berasal dari kran (tap water) untuk menghilangkan semua kotoran yang menempel pada kulit, kemudian dikupas menggunakan alat pengupas manual. Kemudian, labu yang sudah dikupas dibelah dan dipisahkan bagian biji dan isinya dengan bagian daging buah. Selanjutnya dipotong dan diiris dengan ketebalan 2-4 mm, direndam dengan larutan sodium metabisulfit (D.S.P Reagent, South Korea) $0,2 \%$ selama 15, 30, dan 45 menit. Setelah perendaman, chips labu kuning dihamparkan secara merata diatas tray dehydrator sampai tidak ada air yang menetes dari chips. Kemudian dikeringkan dengan menggunakan dehydrator (Jeongigeonjogi DS$120 \mathrm{AC}$, South Korea). Setelah dikeringkan pada suhu 75,80 , dan $85^{\circ} \mathrm{C}$ dalam waktu 8,10 , dan 12 jam, chips labu kuning kering digiling menggunakan grain miller (Tefal BL-120, French) selama 1 menit tanpa dilakukan pengayakan. Kemudian tepung labu ku- 
ning dimasukkan dalam kantung plastik polietilena (PE) dan diikat erat untuk menghindari penyerapan uap air dari lingkungan penyimpanan sampai analisis lebih lanjut.

\section{Proses optimasi}

Pada penelitian ini, desain penelitian didasarkan pada konstruksi Box-Behnken (Vuong et al., 2011) yang terdiri dari 12 perlakuan faktorial dan 5 ulangan titik tengah perlakuan. Faktor perlakuan sebagai variabel independen adalah waktu perendaman metabisulfit (X1), suhu pengeringan (X2) dan waktu pengeringan (X3). Pemilihan variabel independen didasarkan pada penelitian sebelumnya (Que et al., 2008; Aydin dan Gocmen, 2015) yang menunjukkan bahwa variable pengeringan dan penggunaan metabisulfit sebagai medium perendam memberikan pengaruh signifikan terhadap aktivitas antioksidan dan sifat fungsional tepung labu kuning, sehingga perlu dilakukan optimasi. Masing-masing variabel independen tersebut terdiri dari 3 level yaitu: $X_{1}$ adalah 15,30 dan 45 menit, $X_{2}$ adalah 75 , 80 , dan $85^{\circ} \mathrm{C}, \mathrm{X} 3$ adalah 8,10 , dan 12 jam. Sedangkan variabel respon utama yang diukur adalah total aktivitas antioksidan (DPPH dan ABTS). Untuk melakukan optimasi menggunakan RSM maka nilai dari variabel independen harus ditransformasi menjadi variabel terkode (coded variables). Independen variabel dan variabel terkode pada optimasi proses pembuatan tepung labu kuning ditampilkan pada Tabel 1. Persamaan polinomial orde ke-2 digunakan untuk mengekspresikan variabel respon sebagai fungsi dari variabel-variabel independen berdasarkan formula berikut (Vuong et al., 2011).

$Y=\beta o+\sum_{i=1}^{k} \beta i X i+\sum_{i=1}^{k} \sum_{j=2}^{k} \beta i j X i X j+\sum_{i=1}^{k} \beta i i X_{i}^{2}$ dimana Xi dan Xj merupakan variabel independen, $Y$ merupakan variabel respon, sementara $\beta o, \beta i, \beta i i, \beta i j$ merupakan koofisien regresi dan $k$ merupakan jumlah dari variabel. Berdasarkan persamaan 2, variabel respon merupakan fungsi dari variabel independen menurut persaman berikut:

$$
\begin{aligned}
Y i= & \beta 0+\beta 1 X 2+\beta 3 X 3+\beta 12 X 1 X 2+\beta 13 X 1 X 3+\beta 23 X 2 X 3+ \\
& \beta 11 X_{2}^{2}+\beta 33 X_{3}^{3} \ldots \ldots \ldots \ldots \ldots \ldots \ldots \ldots \ldots \ldots \ldots \ldots \ldots \ldots \ldots \ldots \ldots \ldots \ldots \ldots
\end{aligned}
$$

Data percobaan dianalisis dan dihitung variabel respon prediksinya dengan menggunakan software Design Expert 6.0. Proses optimasi dan kontruksi kurva respon prediksi dalam bentuk plot 2-dimensi dan 3-dimensi RSM juga dilakukan dengan menggunakan Design Expert 6.0. Uji signifikan variabel respon dilakukan pada $P<0,05$. Setelah dilakukan optimasi menggunakan RSM, percobaan tambahan dilakukan untuk memverifikasi dan memvalidasi model persamaan optimasi yang telah diperoleh.

\section{Ekstraksi sampel untuk analisis antioksidan}

Ekstraksi sampel tepung labu kuning dilakukan menurut metode Que et al. (2008) yang dimodifikasi. Tepung labu kuning 20 gram ditimbang dan dimasukkan kedalam labu erlenmeyer $250 \mathrm{~mL}$. Kemudian ditambahkan metanol (Duksan Pure Chemical Co., LTD) $50 \mathrm{~mL}$. Ekstraksi dilakukan menggunakan rotary shaker (JS Research JSSI-300C, South Korea) pada suhu $25^{\circ} \mathrm{C}$ selama 10 jam dengan kecepatan $180 \mathrm{rpm}$. Selanjutnya, supernatant disaring menggunakan kertas Whatman No. 1 (GE Healthcare UK Limited, UK) dan disimpan pada suhu $5^{\circ} \mathrm{C}$ sampai analisis lebih lanjut.

Tabel 1. Rancangan perlakuan berdasarkan kontruksi Box-Behnken untuk variable lama perendaman, suhu

\begin{tabular}{|c|c|c|c|c|c|c|}
\hline RUN & \multicolumn{3}{|c|}{$\begin{array}{l}\text { Variabel Terkode } \\
\text { (Coded Variables) }\end{array}$} & $\begin{array}{l}\text { Lama Perendaman Bisulfit } \\
\text { (Menit) }\end{array}$ & $\begin{array}{l}\text { Suhu Pengeringan } \\
\left({ }^{\circ} \mathrm{C}\right)\end{array}$ & $\begin{array}{l}\text { Lama Pengeringan } \\
\text { (Jam) }\end{array}$ \\
\hline 1 & 1 & 0 & 1 & 45 & 80 & 12 \\
\hline 2 & 0 & 1 & 1 & 30 & 85 & 12 \\
\hline 3 & 0 & 0 & 0 & 30 & 80 & 10 \\
\hline 4 & 0 & -1 & 1 & 30 & 75 & 12 \\
\hline 5 & 0 & 0 & 0 & 30 & 80 & 10 \\
\hline 6 & -1 & -1 & 0 & 15 & 75 & 10 \\
\hline 7 & 0 & 1 & -1 & 30 & 85 & 8 \\
\hline 8 & -1 & 0 & 1 & 15 & 80 & 12 \\
\hline 9 & 1 & 1 & 0 & 45 & 85 & 10 \\
\hline 10 & 0 & 0 & 0 & 30 & 80 & 10 \\
\hline 11 & 1 & -1 & 0 & 45 & 75 & 10 \\
\hline 12 & 1 & 0 & -1 & 45 & 80 & 8 \\
\hline 13 & 0 & 0 & 0 & 30 & 80 & 10 \\
\hline 14 & 0 & 0 & 0 & 30 & 80 & 10 \\
\hline 15 & -1 & 1 & 0 & 15 & 85 & 10 \\
\hline 16 & 0 & -1 & -1 & 30 & 75 & 8 \\
\hline 17 & -1 & 0 & -1 & 15 & 80 & 8 \\
\hline
\end{tabular}
pengeringan dan lama pengeringan 


\section{Uji 2,2-Diphenyl-1-picrylhydrazyl (DPPH)}

Uji aktivitas scavenging DPPH dilakukan berdasarkan metode Hossain et al. (2017) yang dimodifikasi. Sampel $0,1 \mathrm{~mL}$ ditambah dengan $0,2 \mathrm{mM}$ DPPH (Sigma-Aldrich, USA) sebanyak $3,9 \mathrm{~mL}$. Selanjutnya, mixture didiamkan selama 30 menit pada suhu ruang. Absorbansi mixture diukur dengan menggunakan spektrofotometer (Shimadzu UV1601, Japan) pada panjang gelombang $510 \mathrm{~nm}$. Aktivitas antioksidan sampel dihitung berdasarkan rumus berikut:

$$
\% \text { Scavenging DPPH }=\left[\frac{(\text { A kontrol-A sampel })}{A \text { kontrol }}\right] \times 100 \%
$$

dimana, A kontrol adalah absorbansi larutan DPPH tanpa penambahan sampel dan A sampel adalah absorbansi larutan DPPH dengan penambahan sampel.

\section{Uji 2,2'-azino-bis (3-ethylbenzothiazoline-6-sul- phonic acid (ABTS)}

Uji aktivitas scavenging ABTS dilakukan berdasarkan metode Hossain et al. (2017) dengan sedikit modifikasi. ABTS (Sigma-Aldrich, USA) 7,4 mM $(0,203 \mathrm{~g}$ per $50 \mathrm{~mL})$ dan potassium persulfate (D.S.P reagent, South Korea) 2,6 mM (0,035 g per $50 \mathrm{~mL}$ ) dicampur dengan perbandingan yang sama. Mixture dimasukkan kedalam botol berwarna gelap dan didiamkan pada tempat gelap selama 12 jam. Dari stok larutan ABTS yang telah disiapkan sebelumnya diambil $1,5 \mathrm{~mL}$ dan diencerkan dengan etanol (Duksan Pure Chemical Co. LTD, South Korea) 23,5 mL. Untuk pengujian, sampel sebanyak $0,01 \mathrm{~mL}$ dicampur dengan larutan ABTS $2,9 \mathrm{~mL}$, didiamkan selama 7 menit dan diukur absorbansinya dengan menggunakan spektrofotometer (Shimadzu
UV-1601, Japan) pada panjang gelombang $734 \mathrm{~nm}$. Aktivitas antioksidan sampel dihitung berdasarkan rumus berikut:

$$
\% \text { Scavenging ABTS }=100-\left[\left(\frac{\text { A sampel }}{\text { A kontrol }}\right) \times 100\right]
$$

dimana, A sampel adalah nilai absorbansi larutan ABTS yang dicampur dengan sampel dan A kontrol adalah nilai absorbansi larutan ABTS tanpa sampel.

\section{HASIL DAN PEMBAHASAN}

\section{Pengembangan model untuk memprediksi aktivi- tas antioksidan}

Pengaruh perendaman metabisulfit, suhu pengeringan dan lama pengeringan terhadap aktivitas antioksidan (DPPH dan ABTS) tepung labu kuning ditampilkan pada Tabel 2. Berdasarkan data respon pada Tabel 2. dilakukan analisis menggunakan software Design Expert untuk menentukan model yang tepat dalam memprediksi hubungan antara perlakuan dengan respon utama yaitu aktivitas antioksidan. Model yang dipilih adalah model yang dapat menjelaskan keeratan hubungan antara variabel perlakuan dan variabel respon yang ditunjukkan dengan nilai koefisien determinasi yang tinggi $\left(R^{2}\right)$. Tabel 3 menunjukkan bahwa berdasarkan model kuadratik, perendaman metabisulfit tidak berpengaruh $(P<0,05)$ terhadap aktivitas antioksidan (DPPH dan ABTS) tepung labu kuning. Sedangkan suhu pengeringan dan lama pengeringan berpengaruh signifikan $(P<0,05)$ terhadap aktivitas antioksidan tepung labu kuning. Pengaruh signifikan kuadratik interaksi suhu pengeringan dan lama pengeringan terjadi pada DPPH.

Tabel 2. Pengaruh perendaman metabisulfit, suhu pengeringan dan lama pengeringan terhadap aktivitas antioksidan (DPPH dan ABTS) tepung labu kuning

\begin{tabular}{ccccccccc}
\hline RUN & \multicolumn{3}{c}{$\begin{array}{c}\text { Coded } \\
\text { Variables }\end{array}$} & $\begin{array}{c}\text { Metabisulphite Immersion } \\
(\text { Min) }\end{array}$ & $\begin{array}{r}\text { Drying Temperature } \\
\left({ }^{\circ} \mathrm{C}\right)\end{array}$ & $\begin{array}{c}\text { Drying Time } \\
(\mathrm{h})\end{array}$ & $\begin{array}{c}\text { DPPH } \\
(\%)\end{array}$ & $\begin{array}{c}\text { ABTS } \\
(\%)\end{array}$ \\
\hline 1 & 1 & 0 & 1 & 45 & 80 & 12 & 83,74 & 62,34 \\
2 & 0 & 1 & 1 & 30 & 85 & 12 & 89,63 & 94,88 \\
3 & 0 & 0 & 0 & 30 & 80 & 10 & 80,85 & 55,80 \\
4 & 0 & -1 & 1 & 30 & 75 & 12 & 65,44 & 41,59 \\
5 & 0 & 0 & 0 & 30 & 80 & 10 & 86,07 & 68,92 \\
6 & -1 & -1 & 0 & 15 & 75 & 10 & 67,26 & 37,93 \\
7 & 0 & 1 & -1 & 30 & 85 & 8 & 88,76 & 85,76 \\
8 & -1 & 0 & 1 & 15 & 80 & 12 & 87,67 & 73,30 \\
9 & 1 & 1 & 0 & 45 & 85 & 10 & 89,09 & 91,33 \\
10 & 0 & 0 & 0 & 30 & 80 & 10 & 85,47 & 67,74 \\
11 & 1 & -1 & 0 & 45 & 75 & 10 & 65,42 & 39,84 \\
12 & 1 & 0 & -1 & 45 & 80 & 8 & 76,03 & 51,26 \\
13 & 0 & 0 & 0 & 30 & 80 & 10 & 84,77 & 62,09 \\
14 & 0 & 0 & 0 & 30 & 85 & 10 & 85,69 & 67,72 \\
15 & -1 & 1 & 0 & 15 & 75 & 10 & 89,18 & 83,62 \\
16 & 0 & -1 & -1 & 30 & 80 & 8 & 53,88 & 35,01 \\
17 & -1 & 0 & -1 & 15 & & 8 & 79,46 & 53,97 \\
\hline
\end{tabular}


Tabel 3. Analisis varians berdasarkan respon surface dengan model kuadratik untuk aktivitas antioksidan (DPPH dan ABTS)

\begin{tabular}{|c|c|c|c|c|c|c|c|c|}
\hline \multirow{2}{*}{$\begin{array}{l}\text { Para- } \\
\text { meters }\end{array}$} & \multicolumn{4}{|c|}{ DPPH Scavenging Activity } & \multicolumn{4}{|c|}{ ABTS Scavenging Activity } \\
\hline & $\begin{array}{c}\text { Predicted } \\
\text { Coefficients }\end{array}$ & $\begin{array}{l}\text { Standard } \\
\text { Error }\end{array}$ & $D F$ & $P$ Value & $\begin{array}{c}\text { Predicted } \\
\text { Coefficients }\end{array}$ & $\begin{array}{l}\text { Standard } \\
\text { Error }\end{array}$ & $D F$ & $P$ Value \\
\hline Model & 84,57 & 1,14785 & 9 & $<0,0001$ & 64,45 & 2,52204 & 9 & 0,0004 \\
\hline A & $-1,16$ & 0,90746 & 1 & 0,2414 & $-0,51$ & 1,99384 & 1 & 0,8069 \\
\hline$B$ & 13,08 & 0,90746 & 1 & $<0,0001$ & 25,15 & 1,99384 & 1 & $<0,0001$ \\
\hline $\mathrm{C}$ & 3,54 & 0,90746 & 1 & 0,0059 & 5,76 & 1,99384 & 1 & 0,0233 \\
\hline$A B$ & 0,44 & 1,28334 & 1 & 0,7432 & 1,45 & 2,81972 & 1 & 0,6229 \\
\hline$A C$ & $-0,13$ & 1,28334 & 1 & 0,9251 & $-2,06$ & 2,81972 & 1 & 0,4883 \\
\hline $\mathrm{BC}$ & $-2,67$ & 1,28334 & 1 & 0,0758 & 0,64 & 2,81972 & 1 & 0,8283 \\
\hline$A^{2}$ & 0,23 & 1,25084 & 1 & 0,8578 & $-2,68$ & 2,74833 & 1 & 0,3614 \\
\hline $\mathrm{B}^{2}$ & $-7,07$ & 1,25084 & 1 & 0,0008 & 1,41 & 2,74833 & 1 & 0,6239 \\
\hline $\mathrm{C}^{2}$ & $-3,08$ & 1,25084 & 1 & 0,0434 & $-1,55$ & 2,74833 & 1 & 0,5896 \\
\hline $\mathrm{R}^{2}$ & \multicolumn{4}{|c|}{0,97} & \multicolumn{4}{|c|}{0,96} \\
\hline Lack of fit & \multicolumn{4}{|c|}{0,2500} & \multicolumn{4}{|c|}{0,4457} \\
\hline
\end{tabular}

Berdasarkan model kuadratik, variabel lama perendaman, suhu pengeringan, dan lama pengeringan dengan aktivitas antioksidan memiliki keeratan yang tinggi yang ditunjukkan dengan nilai koefisien determinasi $\left(R^{2}\right)$ masing-masing sebesar 0,97 (DPPH); dan 0,96 (ABTS). Hal tersebut menunjukkan bahwa model kuadratik mampu menjelaskan dengan baik hubungan antara data percobaan dengan data hasil prediksi (Zhang et al., 2009; Hadiyanto dan Suttrisnorhadi, 2016). Nilai lack of fit untuk DPPH dan ABTS masing-masing sebesar 0,2500 ; dan $0,4457 \quad(P>0,05)$ yang berarti tidak signifikan yang menunjukkan bahwa model kuadratik sangat sesuai untuk menduga variabel respon (Hadiyanto dan Suttrisnorhadi, 2016). Jika nilai Lack of Fit signifikan $(P<0,05)$ maka model linier lebih sesuai untuk menduga nilai respon.

Berikut ini adalah persamaan model kuadratik untuk DPPH:

$$
\begin{aligned}
& Y_{1}=84,57-1,16 X_{1}+13,08 X_{2}+3,54 X_{3}+0,44 X_{1} X_{2}- \\
& 0,13 X_{1} X_{3}-2,67 X_{2} X_{3}+0,23 X_{1}^{2}+7,06 X_{2}^{2} \\
& 3,08
\end{aligned}
$$

Persamaan model kuadratik untuk ABTS:

$$
\begin{aligned}
Y_{2}= & 64,45-0,51 X_{1}+25,15 X_{2}+5,76 X_{3}+1,45 X_{1} X_{2}- \\
& 2,06 X_{1} X_{3}+0,63 X_{2} X_{3}-2,68 X_{2}^{1}+1,41 X_{2}^{2}-1,55 X_{3}^{2} .
\end{aligned}
$$

\section{Pengaruh perendaman metabisulfite, suhu pe- ngeringan dan lama pengeringan terhadap akti- vitas antioksidan}

Pengaruh parameter waktu perendaman metabisulfit, suhu pengeringan, dan waktu pengeringan secara independen terhadap aktivitas antioksidan dan profil response surface 2D dan 3D tepung labu kuning ditampikan pada Gambar 1-3.

Gambar 1 menunjukkan bahwa waktu perendaman metabisulfit tidak memberikan pengaruh signifikan terhadap aktivitas antioksidan (DPPH dan AB TS). Semakin lama waktu perendaman metabisulfit tidak menunjukkan pola penurunan maupun peningkatan aktivitas antioksidan. Hal ini sesuai dengan hasil analisis varian model kuadratik bahwa perendaman metabisulfit menghasilkan nilai DPPH dan ABTS masing-masing sebesar 0,2414 dan 0,8069 $(P>0,05)$, yang berarti tidak memberikan pengaruh signifikan. Sebaliknya, Aydin dan Gocmen (2015) melaporkan bahwa perendaman awal dengan metabisulfit dalam pembuatan tepung labu kuning dapat meningkatkan aktivitas antioksidan dibandingkan sampel yang tidak direndam metabisulfit. Peningkatan aktivitas antioksidan kemungkinan disebabkan oleh meningkatnya kandungan fenol pada sampel yang direndam dengan metabisulfit. Perendaman dengan metabisulfit diduga memberi efek proteksi terhadap senyawa fenolik seperti carotenoid dan neoxanthin pada mangga. Sulfit sendiri merupakan senyawa antioksidan multifungsi. Sodium atau Kalsium bisulfit digunakan untuk menstabilkan warna buah. Seperti halnya vitamin C, sulfit merupakan penerima oksigen dan menghambat aktivitas enzim pengoksidasi. Sulfit juga menghambat reaksi Maillard melalui reaksi dengan gugus aldehid pada gula sehingga tidak bebas lagi untuk bereaksi dengan asam amino (Oke et al., 2012). Dalam penelitian ini sampel direndam dengan metabisulfit dengan waktu yang berbeda. Perendaman dengan waktu yang berbeda ternyata tidak memberikan pengaruh signifikan terhadap aktivitas antioksidan tepung labu kuning.

Gambar 2 menunjukkan pengaruh suhu pengeringan terhadap aktivitas antioksidan tepung labu kuning berdasarkan pengujian DPPH (A), dan ABTS (B). Peningkatan suhu pengeringan pada proses pembuatan tepung labu kuning berkorelasi positif dengan aktivitas antioksidan (DPPH dan ABTS). Pengaruh suhu pengeringan terhadap DPPH menunjukkan pola kuadratik (Gambar 2A). Sedangkan pengaruhnya pada ABTS menunjukkan pola linier (Gambar 2B). 

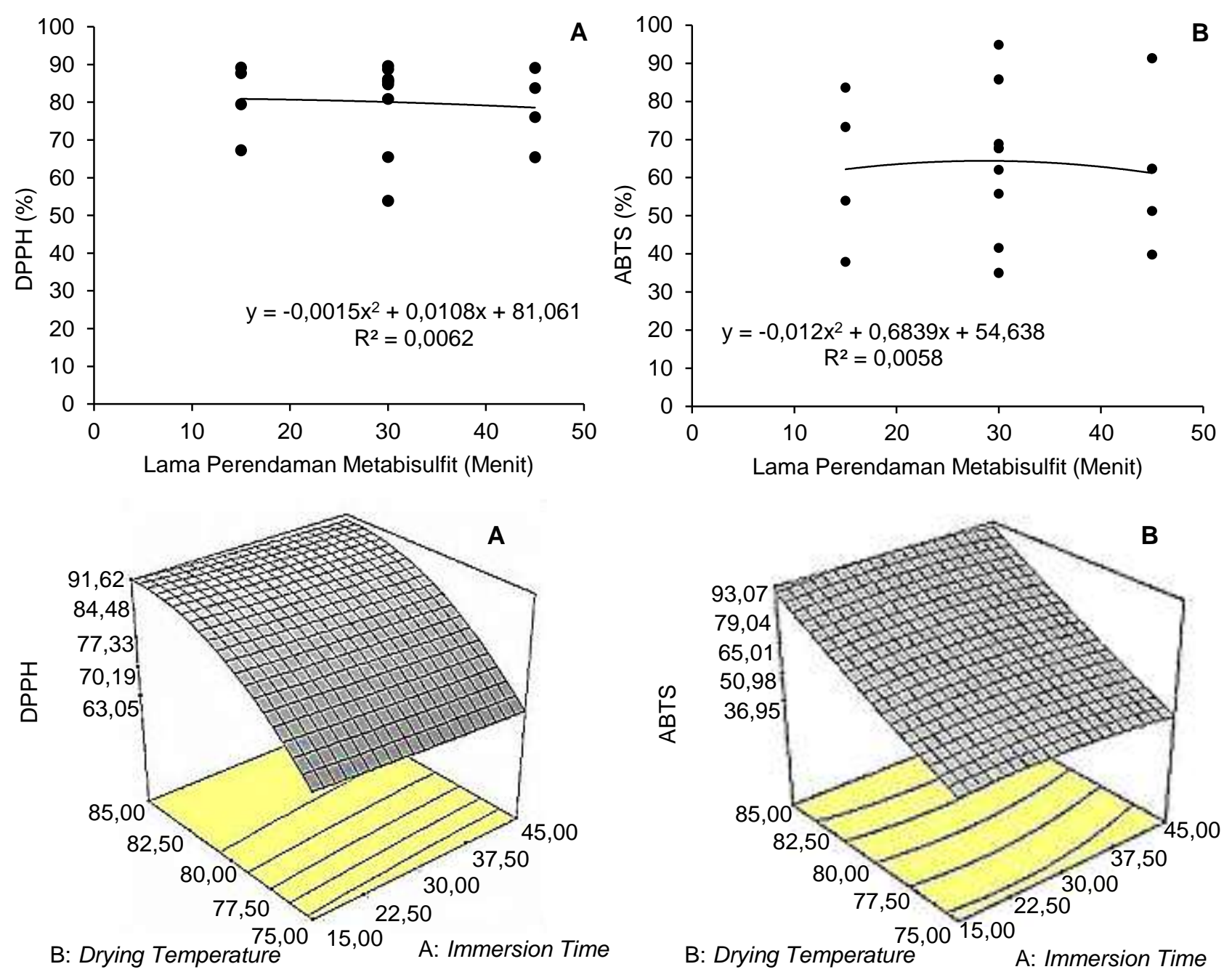

Keterangan: $\mathrm{A}=\mathrm{DPPH} ; \mathrm{B}=\mathrm{ABTS}$

Gambar 1. Pengaruh parameter lama perendaman metabisulfit secara independen (Gambar atas) terhadap aktivitas antioksidan dan profil response surface 2D dan 3D (Gambar bawah) tepung labu kuning

Berdasarkan analisis varian model kuadratik menunjukkan bahwa suhu pengeringan berpengaruh signifikan $(P<0,05)$ terhadap $\mathrm{DPPH}$, dan ABTS dengan nilai $P$ masing-masing sebesar $<0,0001$ dan $<0,0001$. Telah dilaporkan bahwa pengeringan pada suhu $60^{\circ} \mathrm{C}$ (Aydin dan Gocmen, 2015) dan $70^{\circ} \mathrm{C}$ (Que et al., 2008) meningkatkan aktivitas antioksidan tepung labu kuning. Beberapa peneliti lain juga melaporkan peningkatan aktivitas antioksidan dengan pengeringan suhu tinggi pada kopi (SanchezGonzalez et al., 2005) dan tepung biji manga (Soong dan Barlow, 2004). Pengeringan dengan suhu tinggi menyebabkan pembentukan senyawa fenol yang bertanggung jawab terhadap aktivitas antioksidan yang lebih tinggi (Que et al., 2008). Beberapa senyawa fenolik yang meningkat konsentrasinya setelah proses pengeringan adalah chlorogenic, syringic, p-hydrobenzoic, caffeic, gallic, p-cou- maric, dan sinapic acid (Aydin dan Gocmen, 2015). Disamping itu, adanya pembentukan komponen lain yang memiliki aktivitas antioksidan seperti produk reaksi Maillard serta deaktivasi enzim oksidasi dan hidrolisis. Lebih lanjut, kandungan total fenol dan aktivitas antioksidan dapat meningkat atau turun setelah pengeringan, tergantung pada jenis komoditas dan sistem produksi yang digunakan (konvensional atau organik) (Lutz et al., 2015). Pengaruh lama pengeringan terhadap aktivitas antioksidan tepung labu kuning disajikan pada Gambar 3. Berdasarkan Gambar 3, dapat dilihat bahwa lama pengeringan memberikan pengaruh dengan pola kuadratik terhadap aktivitas antioksidan. Berdasarkan hasil analisis varian model kuadratik menunjukkan bahwa lama pengeringan berpengaruh signifikan $(P<0,05)$ terhadap $\mathrm{DPPH}$, dan ABTS dengan nilai $P$ masingmasing sebesar 0,0059 dan 0,0233 . 

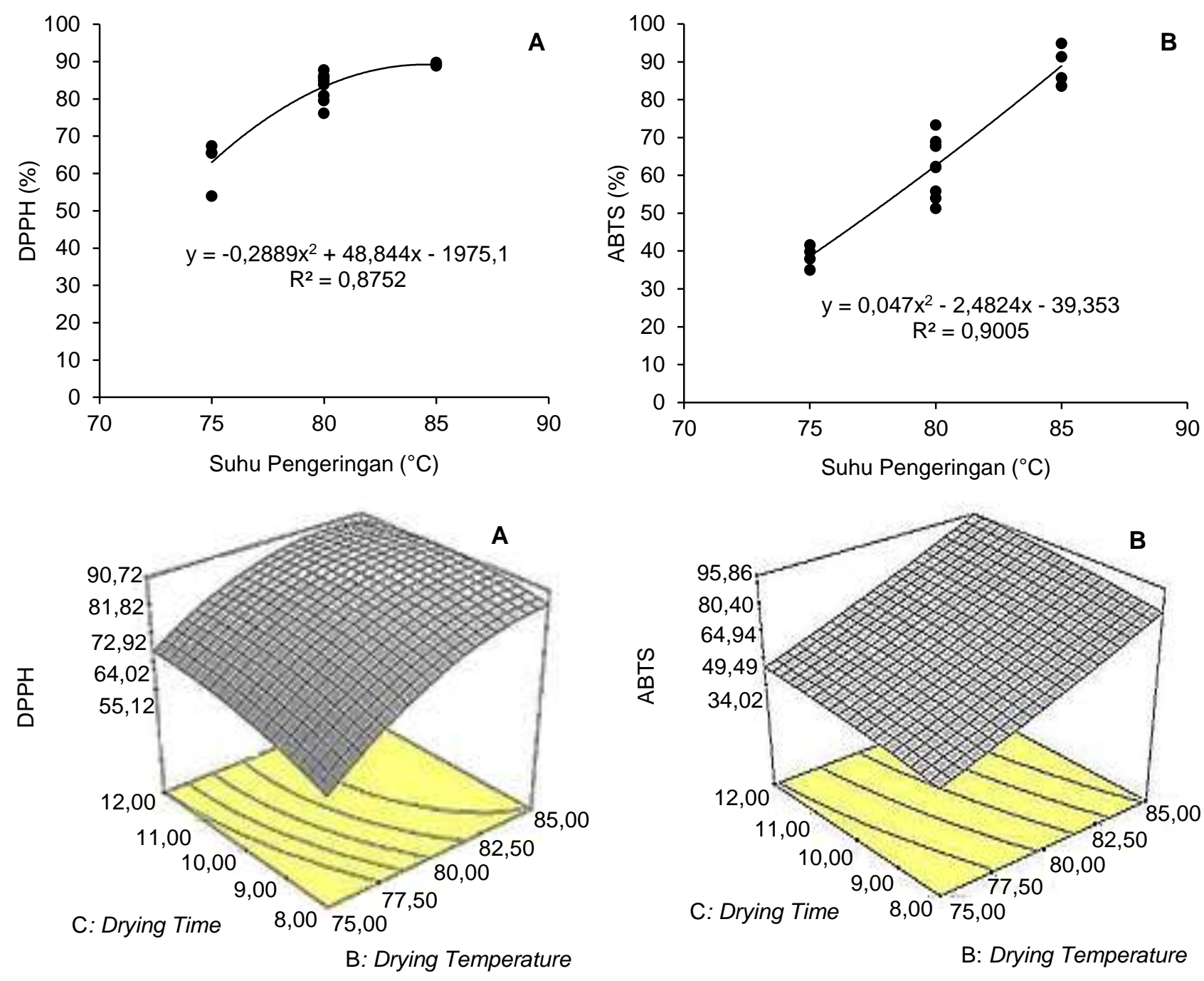

Keterangan: $\mathrm{A}=\mathrm{DPPH} ; \mathrm{B}=\mathrm{ABTS}$

Gambar 2. Pengaruh suhu pengeringan secara independen (Gambar atas) terhadap aktivitas antioksidan dan profil response surface 2D dan 3D (Gambar bawah) tepung labu kuning

Adanya peningkatan aktivitas antioksidan dengan peningkatan lama pengeringan pada tepung labu kuning diduga karena akumulasi senyawa fenol yang lebih banyak. Akan tetapi, beberapa peneliti melaporkan bahwa peningkatan lama pengeringan akan menurunkan aktivitas antioksidan yang disebabkan degradasi senyawa fenolik serta seyawa yang memiliki aktivitas antioksidan kehilangan kestabilannya (Ibrahim et al., 2015; Planinić et al., 2015).

\section{Optimasi dan validasi proses pembuatan tepung labu kuning dengan response surface method- logy}

Model regresi yang diperoleh pada persamaan 3 dan 4 digunakan untuk menentukan nilai optimum waktu perendaman (X1), suhu pengeringan (X2) dan waktu pengeringan (X3) dengan menggunakan prosedur optimasi pada software Design Expert versi 6.
Optimasi dilakukan untuk mendapatkan aktivitas antioksidan (DPPH dan ABTS) maksimum secara simultan. Berdasarkan hasil optimasi, diperoleh nilai optimum waktu perendaman metabisulfit 23,05 menit, suhu pengeringan $85^{\circ} \mathrm{C}$ dan waktu pengeringan 10,40 jam. Kondisi optimum tersebut diprediksi menghasilkan aktivitas antioksidan berdasarkan uji DPPH dan uji ABTS sebesar 91,12 dan 94,38\%.

Validasi merupakan percobaan tambahan yang dilakukan untuk mengetahui kekuatan model persamaan yang telah dihasilkan dari proses optimasi. Berdasarkan hasil optimasi yang telah dilakukan maka diproduksi tepung labu kuning dengan kondisi proses perendaman metabisulfit 23,05 menit, suhu pengeringan $85^{\circ} \mathrm{C}$ dan waktu pengeringan 10,40 jam. Kemudian tepung labu kuning yang dihasilkan dianalisis aktivitas antioksidannya. Hasil percobaan validasi disajikan pada Tabel 4. 

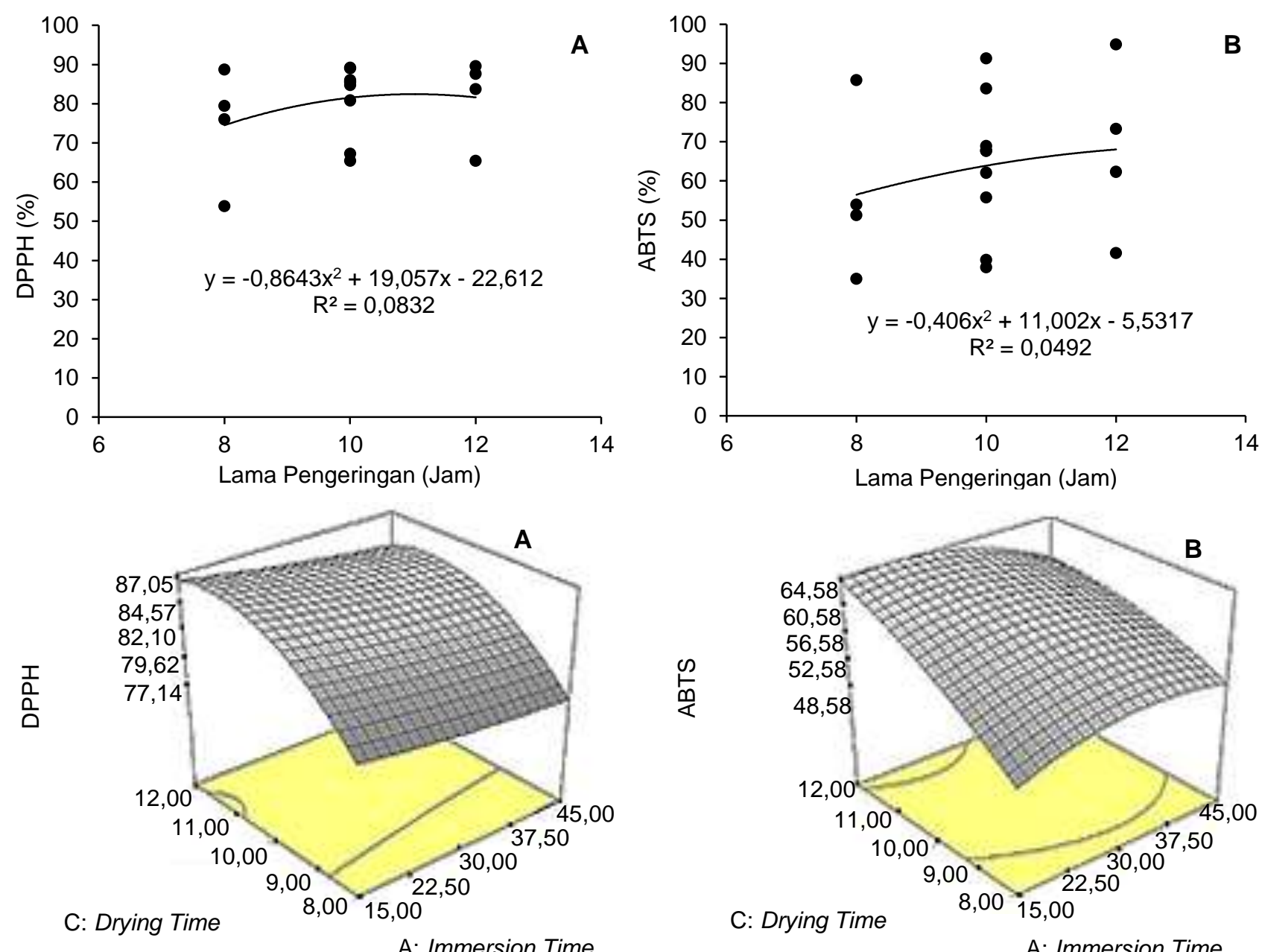

A: Immersion Time

Keterangan: $\mathrm{A}=\mathrm{DPPH} ; \mathrm{B}=\mathrm{ABTS}$

Gambar 3. Pengaruh lama pengeringan secara independen (Gambar atas) terhadap aktivitas antioksidan dan profil response surface 2D dan 3D (Gambar bawah) tepung labu kuning. DPPH (A) dan ABTS (B)

Tabel 4. Perbandingan antara nilai prediksi dan nilai aktual aktivitas antioksidan tepung labu kuning

\begin{tabular}{cccccc}
\hline No. & Variabel Respon & \multicolumn{1}{c}{ Kondisi Optimum } & Nilai Prediksi & Nilai Aktual & Akurasi (\%) \\
\hline 1 & DPPH (\%) & $\begin{array}{l}\text { Perendaman: } 23,05 \text { menit } \\
\text { Suhu pengeringan: } 85^{\circ} \mathrm{C}\end{array}$ & 90,12 & 80,23 & 89,02 \\
& Lama pengeringan: 11,40 jam & & & \\
2 & ABTS (\%) & & 94,38 & 86,67 & 91,83 \\
\hline
\end{tabular}

Berdasarkan Tabel 4. menunjukkan bahwa percobaan validasi dengan kondisi optimum menghasilkan tepung labu kuning dengan aktivitas antioksidan DPPH dan ABTS masing-masing 80,23 dan $86,67 \%$. Presentase akurasi model untuk memprediksi nilai aktual aktivitas antioksidan DPPH dan ABTS masing-masing sebesar 89,02 dan $91,83 \%$. Hal ini menunjukkan bahwa model prediksi mampu menduga nilai aktual parameter respon dengan tingkat ketelitian yang cukup tinggi. Beberapa peneliti terdahulu telah membuktikan kehandalan model prediksi dengan menggunakan RSM. Seperti yang dilaporkan oleh Zhang et al. (2009) yang melakukan ekstraksi minyak almond dengan metode ultrasound assisted extraction. Mereka membuktikan validitas model RSM dengan adanya hasil aktual minyak almond $(81,89 \%)$ yang tidak berbeda signifikan ( $P>$ $0,05)$ dengan hasil prediksi minyak almond (82, 10\%). Deshmukh et al. (2017) membuktikan kekuatan model RSM untuk optimasi karakteristik fungsional, kadar antioksidan, dan sifat fisikokimia bubuk labu kuning. Mereka membuktikan bahwa nilai aktual percobaan parameter tersebut diatas sangat dekat dengan nilai prediksi dengan coefisien of varian (COV) lebih rendah dari $8,37 \%$. 
Sedangkan Hadiyanto dan Suttrisnor hadi (2016) menunjukkan kekuatan model RSM dalam proses optimasi ekstraksi menggunakan ultra-sound terhadap hasil phycocyanin dan aktivitas antioksidan mikroalga Spirulina platensis. Mereka melaporkan bahwa kadar phycocyanin dan aktivitas antioksidan mikroalga Spirulina platensis dari percobaan tidak significan $(P>0,05)$ terhadap nilai hasil prediksi.

\section{KESIMPULAN}

Perendaman natrium metabisulfit tidak berpengaruh signifikan terhadap aktivitas antioksidan yang diukur sebagai aktivitas reduksi DPPH dan ABTS. Sedangkan pengaruh waktu pengeringan dan suhu pengeringan berpengaruh signifikan terhadap aktivitas antioksidan. Nilai koefisien determinasi $\left(R^{2}\right)$ untuk DPPH dan ABTS masing-masing adalah 0,97 dan 0,96 yang menunjukkan keeratan hubungan antara model prediksi dengan nilai aktual. Berdasarkan model prediksi, diperoleh kondisi optimum untuk memproduksi tepung labu kuning yaitu perendaman natrium metabisulfit 23,05 menit, suhu pengeringan $85^{\circ} \mathrm{C}$, dan waktu pengeringan 11,40 jam. Kondisi optimum tersebut diprediksi dapat menghasilkan tepung labu kuning dengan aktivitas antioksidan masing-masing sebesar 90,12\% untuk DPPH dan $94,38 \%$ untuk ABTS. Uji konfirmasi dengan kondisi optimum menghasilkan tepung labu kuning dengan aktivitas antioksidan DPPH dan ABTS masing-masing 80,23 dan $86,67 \%$. Presentase akurasi model untuk memprediksi nilai aktual aktivitas antioksidan DPPH dan ABTS masingmasing sebesar 89,02 dan $91,83 \%$. Hal ini menunjukkan bahwa model prediksi mampu menduga nilai aktual parameter respon dengan tingkat ketelitian yang cukup tinggi.

\section{UCAPAN TERIMA KASIH}

Penulis berterima kasih kepada Kementerian Riset dan Teknologi melalui Penelitian Produk Terapan dengan Kontrak Penelitian Nomor 310/PL17. 4/PL/2017 tanggal 06 April 2017, Politeknik Negeri Jember dan Department of Food and Food Service Industry, Kyungpook National University, Korea yang telah memfasilitasi penelitian ini.

\section{DAFTAR PUSTAKA}

Adams GG, Imran S, Wang S, Mohammad A, Kok S, Gray DA, Harding SE. 2011. The hypoglycaemic effect of pumpkins as antidiabetic and functional medicines. Food Res Int 44: 862867. DOI: 10.1016/j.foodres.2011.03.016.
Aydin E, Gocmen D. 2015. The influences of drying method and metabisulfite pre-treatment on the color, functional properties and fenolik acids contents and bioaccessibility of pumpkin flour. LWT-Food Sci Technol 60: 385-392. DOI: 10. 1016/j.Iwt.2014.08.025.

Chen $H Q$, Chen XM, Chen TX, Xu XM, Jin ZY. 2011. Optimization of solid-state medium for the production of inulinase by Aspergillus ficuum JNSP5-06 using response surface methodology. Carbohyd Polym 86: 249-254. DOI: 10. 1016/j.carbpol.2011.04.044.

Deshmukh Y, Sharma HK, Kumar N. 2017. Modeling of physicochemical and functional parameters of pumpkin (Cucurbita pepo) powder using response surface methodology. Int Food Res $\mathrm{J}$ 24: 2071-2081.

Dhiman AK, Sharma KD, Attri S. 2009. Functional constituents and processing of pumpkin - a review. J Food Sci Technol-Mys 46: 411-417.

Guo N, Gong F, Chi Z, Sheng J, Li J. 2009. Enhanced inulinase production in solid state fermentation by a mutant of the marine yeast Pichia guilliermondii using surface response methodology and inulin hydrolysis. J Ind Microbiol Biotechnol 36: 499-507. DOI: 10.1007/s10 295-008-0519-2.

Hadiyanto H, Suttrisnorhadi S. 2016. Response surface optimization of ultrasound assisted extraction (uae) of phycocyanin from microalgae Spirulina platensis. Emir J Food Agr 28: 227-234. DOI: 10.9755/ejfa.2015-05-193.

Hossain A, Moon HK, Kim JK. 2017. Effect of pretreatment and extraction conditions on the antioxidant properties of persimmon (Diospyros kaki) leaves. Biosci, Biotechnol, Biochem 81: 2079-2085. DOI: 10.1080/09168451.2017.1378 088.

Ibrahim UK, Austin EA, Salleh RM. 2015. Effect of drying temperature and time on antioxidant and total fenolik content in Garcinia mangostana Pericarp. Adv Mat Res 1113: 279-284. DOI: 10. 4028/www.scientific.net/AMR.1113.279.

Khuri Al, Mukhopadhyay S. 2010. Response surface methodology. WIREs Comp Stat 2: 128-149. DOI: 10.1002/wics.73.

Lutz M, Hernández J, Henríquez, C. 2015. Fenolik content and antioxidant capacity in fresh and dry fruits and vegetables grown in Chile. CyTAJ Food 13: 541-547. DOI: 10.1080/19476337. 2015.1012743.

Myers RH, Montgomery DC, Anderson-Cook CM. 2016. Response Surface Methodology: Process and Product Optimization using Designned Experiments. 1-2. Wiley and Sons Inc. New Jersey. 
Oke M, Jacob JK, Paliyath G. 2012. Biochemistry of fruit processing.in "Food Biochemistry and Food Processing", Simpson, B.K. (Ed.), John Wiley and Sons Inc., Blackwell Publishing. Chapter $28^{\text {th }}$. DOI: $10.1002 / 9781118308035$.ch28.

Peričin D, Radulović-Popović L, Vaštag Ž, MadarevPopović S, Trivić S. 2009. Enzymatic hydrolysis of protein isolate from hull-less pumpkin oil cake: Application of response surface methodology. Food Chem 115: 753-757. DOI: 10.10 16/j.foodchem.2008.12.040.

Planinić M, Aliakbarian B, Perego P, Greganić K, Tomas S. 2015. Influence of temperature and drying time on extraction yield of fenolik compounds from grape pomace variety "Portogizac". Chem Biochem Eng 29: 343-350. DOI: 10.15255/CABEQ.

Que F, Mao L, Fang X, Wu T. 2008. Comparison of hot air-drying and freeze-drying on the physicchemical properties and antioxidant activities of pumpkin (Cucurbita moschata Duch.) flours. Int J Food Sci Technol 43: 1195-1201. DOI: 10.11 11/j.1365-2621.2007.01590.x

Rakcejeva T, Galoburda R, Cude L, Strautniece E. 2011. Use of dried pumpkins in wheat bread production. Procedia Food Sci 1: 441-447. DOI: 10.1016/j.profoo.2011.09.068.

Salinas MV, Puppo MC. 2015. Optimization of the formulation of nutritional breads based on calcium carbonate and inulin. LWT-Food Sci Technol 60: 95-101. DOI: 10.1016/j.Iwt.2014. 08.019 .

Sanchez-Gonzalez I, Jimenez-Escrig A, SauraCalixto F. 2005. In vitro antioxidant activity of coffees brewed using different procedures (Italian, espresso and filter). Food Chem 90: 133139. DOI: 10.1016/j.foodchem.2004.03.037.

Soong YY, Barlow PJ. 2004. Antioxidant activity and fenolik content of selected fruit seeds. Food Chem 88: 411-417. DOI: 10.1016/j.foodchem. 2004.02.003.

Vuong QV, Golding JB, Nguyen MH, Roach PD. 2012. Production of caffeinated and decaffeinated green tea catechin powders from underutilised old tea leaves. J Food Eng 110: 1-8. DOI: 10.1016/j.jfoodeng.2011.12.026.

Zhang QA, Zhang ZQ, Yue XF, Fan XH, Li T, Chen SF. 2009. Response surface optimization of ultrasound-assisted oil extraction from autoclaved almond powder. Food Chem 116: 513518. DOI: 10.1016/j.foodchem.2009.02.071. 